IZA DP No. 9583

Are Working Time Accounts Beneficial for German Establishments?

Lutz Bellmann

Olaf Hübler

December 2015 


\title{
Are Working Time Accounts Beneficial for German Establishments?
}

\author{
Lutz Bellmann \\ Friedrich-Alexander-Universität Erlangen-Nürnberg, \\ $I A B$ and IZA \\ Olaf Hübler \\ Leibniz Universität Hannover, \\ $I A B$ and IZA
}

Discussion Paper No. 9583

December 2015

IZA
P.O. Box 7240
53072 Bonn
Germany

Phone: +49-228-3894-0

Fax: +49-228-3894-180

E-mail: iza@iza.org

\begin{abstract}
Any opinions expressed here are those of the author(s) and not those of IZA. Research published in this series may include views on policy, but the institute itself takes no institutional policy positions. The IZA research network is committed to the IZA Guiding Principles of Research Integrity.

The Institute for the Study of Labor (IZA) in Bonn is a local and virtual international research center and a place of communication between science, politics and business. IZA is an independent nonprofit organization supported by Deutsche Post Foundation. The center is associated with the University of Bonn and offers a stimulating research environment through its international network, workshops and conferences, data service, project support, research visits and doctoral program. IZA engages in (i) original and internationally competitive research in all fields of labor economics, (ii) development of policy concepts, and (iii) dissemination of research results and concepts to the interested public.
\end{abstract}

IZA Discussion Papers often represent preliminary work and are circulated to encourage discussion. Citation of such a paper should account for its provisional character. A revised version may be available directly from the author. 


\section{ABSTRACT}

\section{Are Working Time Accounts Beneficial for German Establishments?*}

This contribution investigates whether working time accounts are beneficial for the performance of German establishments. Based on the representative German Establishment Panel of the Institute for Employment Research during the period 2008-2013, effects on productivity, wages, sales, firm size, investments, further training, labor mobility, working hours, operating surplus and profits as performance indicators are estimated. Heterogeneity and robustness are investigated by a subgroup analysis where we distinguished between establishments with a high and a low share of qualified workers, between firms with strong and weak sales fluctuations. Additionally, different lengths of the agreed compensation period and reasons for longer time out periods of the employees are considered. Unobserved firm effects as well as interdependencies between important performance indicators and working time accounts are analyzed. OLS estimates, Lewbel's instrumental estimator and IV panel approaches are applied. As major results we find that productivity and investments are positively correlated with working time accounts. No significant effects of working time accounts can be detected on wages, the number of employees and operating surplus of IV panel estimates. However, on average, we find a tendency towards negative effects on profits. This result is less likely in establishments with a high share of skilled workers. Under strong sales fluctuations we find positively significant on the operating surplus. These mixed results hint to a conflict between the employers and employees interests concerning working time accounts that result in compromise solutions.

JEL Classification: $\quad$ C22, D21, J21, J22

Keywords: flexible working time, working time accounts, establishments, productivity, wages, labor mobility, operating surplus, profits, share of qualified workers, sales fluctuations, compensation period

Corresponding author:

Olaf Hübler

Institut für Empirische Wirtschaftsforschung

Leibniz Universität Hannover

Königsworther Platz 1

30167 Hannover

Germany

E-mail: huebler@ewifo.uni-hannover.de

\footnotetext{
* We are grateful to Michael Beckmann, Thomas Cornelissen, Knut Gerlach, Hans-Dieter Gerner, Robert A. Hart and Wolfgang Meyer for their helpful comments.
} 


\section{Introduction}

Discussion of flexible working time has a long tradition in the economic, psychological and sociological literature (Berg et al. 2004, Crompton 2002, Dex/Scheibl 2001, Houseman 2001, Kelliher/Anderson 2010, Orpen 1981, Schein et al. 1977). Although it is pointed out that flexible working time is in the interest of both employees and employers, most studies concentrate on employee effects. Therefore, our contribution is focused on the establishments' perspective. Working time accounts (WTA) or time banks are a specific instrument to allow some working time flexibility around a planned working time framework. The implementation of WTA is associated with fixed costs for the IT-system and requires a careful and precise planning of tasks undertaken by the employees. WTA systems are characterized by relatively large fixed costs and lower variable costs (Ludewig 2001, 304).

Both employers and employees can benefit from WTA (Seifert 2004): employers are interested in the ability to adjust employees daily or weekly working time if demand for and availability of personnel varies over time. They are able to adapt the working volume without layoff and (re-)hiring of personnel. Thus, employers can avoid layoff and recruitment costs. Employees, and especially women, can better combine paid work with care of children and elderly persons, because care cannot be fully pre-planned. Both male and female employees are able to reconcile their work life balance, since e.g. they can spend longer holidays and find time for further training courses. Conflicts may arise because employees' work life balance projects might be in conflict with establishments' requirements. Which effects are stronger depend on the working time typology, whether employer- or employee-preferred variability arrangements dominate (Chung/Tijdens 2009).

WTA increase the worker's control over the time allocation in respect of social and work commitments. They can avoid rush-hour commute. They are better able to take a child to and from school. They benefit from early leave or late start for sports training. Possenriede (2014) discusses possible effects of 
temporal flexibility of work on employee's satisfaction, career, absenteeism, actual working hours. He argues that flexible working time has a positive impact on utility from work in general. Employees can work hours that fit better with their personal needs and their biological clocks. Therefore, more work and life satisfaction is achieved.

Career chances decreases for employees who reduce their working time for longer periods. Human capital depreciation, and less work experience provide two possibilities. They receive less training. In contrast, those who temporarily reduce their working time do not suffer from a loss of human capital. If they are in higher positions they are even awarded. Employers prefer those employees among their staff who are continuously available and who adjust their working time to firms' needs. If this is combined with higher productivity chances of promotion are enhanced.

Theoretical effects of flexible working time are manifold (Golden 2012). Under fixed working time arrangements preferred and actual working hours may differ. In this case employees often use absenteeism as a coping strategy. WTA can help to reduce this problem. Flexible working time also offers better possibilities to deal with minor sickness and associated absenteeism. It is possible that individual working patterns have positive effects on health and less work absences. Whether WTA increase the total number of individual working hours is unclear. Especially for female workers with part-time work an extension of the total number of working hours is more likely. The higher flexibility makes it less necessary to keep some hours in reserve for unexpected activities in the household.

The positive and negative effects of flexible working time on employees also affect firm's profits. Establishments have possibilities to weaken negative and strengthen positive effects. Better capacity utilization can be achieved by WTA and insofar capital costs can be saved and storage costs can be reduced. A more efficient utilization of labor is a central objective of WTA (Zapf 2012). 
Another advantage of WTA for employees and employers is described by Carstensen (2013). She interprets WTA as a mutual insurance between employers and employees. Risks are reduced. WTA partially protect against unemployment. Employers are better able to meet demand fluctuations, and can better avoid the wage costs associated with workforce under-utilization. Additionally, the mutual insurance reduces layoff and the hiring rates as well as their associated costs. Furthermore, it exerts positive dynamic effects on human capital formation. These two aspects are of greater importance for firms, experiencing scarcity of skilled personnel.

Negative effects of WTA are expected if employees use this flexible working time instrument at different times than the employer desires. Firms are interested that working time hours are reduced during a recession. If demand for goods increases they want to expand the scope of work. Overtime hours and therefore positive working time credits are desired. However, workers want to adjust their working hours on their preferred timing, namely between preferred leisure and work trade-off. Whether the interests of employers and employees can be harmonized or whether one side has more advantages depends on the design of WTA.

WTA exist in German plants since the 1960s. The flexible working hours (Gleitzeit) discussion combined with the decoupling of working hours and company operating hours has promoted the breakthrough of this instrument (Groß et al. 2000). In the last years more and more establishments have implemented WTA. In the course of the flexibility debate, of the labor market reforms and the Great Recession this instrument has become more popular. We contribute to the WTA literature by providing a more detailed analysis of working time accounts with respect to firms' effects. First, we discuss the impact of WTA on productivity not only during the Great Recession but over a period of six years including the recession period. This enables permanent effects to be detected. Second, we supplement the investigation of WTA effects on further important business indicators, especially with respect to the wages per employee, the number of employees, working hours, investments and profits. This provides us with insights about the 
question whether WTA have positive effects on firms' performance. Third, subgroup analysis is carried out. We show that the effects differ between establishments with a high and a low share of skilled workers, between companies with strong and only weak sales fluctuations. Moreover, we present the effects of WTA under different agreements on the compensation period within WTA regimes and under different reasons why long-term WTA are used. This reveals whether the WTA effects are heterogeneous with respects to specific WTA contracts. Fourth, a range of econometric methodology is applied to check the robustness and heterogeneity resulting from different WTA arrangements.

The rest of the paper is organized as follows: In section 2, after this introduction, the spectrum of WTA arrangements in German establishments is discussed. This helps to decide, on which WTA contracts the subgroup analysis should be based. Then, in section 3 , the major empirical results of related literature are presented in a brief overview in order to make clear differences to our investigation. Section 4 is focused on the data set and first descriptive statistics, before in section 5 the applied methods and the econometric results are discussed. Section 6 concludes.

\section{Institutional aspects - arrangements of flexible working hours and working time accounts}

Flexible working time has many dimensions and in practice different options are used. Arrangements in different European countries are described in Brewster et al. (1997), Kouzis/Kretsos (2003) and Platenga/Remery (2010). Working time accounts (WTA) can vary between one collective bargaining and another, between one firm and another. Seifert (2004) distinguishes especially three general types: flextime, corridor arrangements and overtime accounts models. These approaches differ in the degree of flexibility. Either, time savings and deficits are allowed with short or longer compensation periods, or only one of these two possibilities can be used. WTA allow adjustments of working hours to sales fluctuations where the monthly wage does not vary with the actual working hours. Specific interest rates of time credits are usually not agreed (Gerlach 2004). One objective of WTA is to avoid overtime working 
with extra payments and short-time work (STW). Compared with a fixed full-time working, time arrangements exist that allow reduced but also fixed hours. Part-time work, job-sharing, shift-work, STW, partial retirement and term-time working belong to this type. Other possibilities of flexibility are longer complete timeout periods like sabbaticals and maternity leave. Employees can use long-term leave for further training but also to take care of family members. Finally, variable daily, weekly, monthly or annual working time can be contractually agreed. The daily options are usually imbedded in a core working time, e.g. from 10 a.m. to 3 p.m. The employee can choose from day to day the actual working time within a given range, e.g. from 6 a.m. to 10 a.m. and 3 p.m. 9 p.m. However, work absence and overtime working have to be compensated over a contracted period. Time-management software is used to register more and less hours compared with the agreed number of working hours per period by WTA. The period of time within which employees have to compensate deviations from standard working hours is important to the question of whether WTA are beneficial for an establishment.

Ludewig (2001) and Lindecke (2008) underline that WTA are often supplemented by maximum feasible deviations from the planned value and sometimes guarantees of jobs are agreed between employer and employees or works councils. Company or collective bargaining agreements can be the basis. In 2007 the upper limit for the number of hours saved was on average 103 hours, the lower limit was equal to 63 hours of debits and the average compensation period was 38 weeks. The range between the average upper and lower limits would have allowed for temporary working-time reduction with the help of WTA of at most 166 hours (Herzog-Stein and Zapf 2014, Groß 2009).

It is an open question whether overtime premiums have to be paid within the WTA bounds. Overtime premiums have not to be paid if overtime hours on one day are compensated by paid leisure time within two weeks. The employer and the works council or individual workers can agree that within a balancing period of 12 months a deviating distribution of the agreed standard working hours without overtime premium is possible if a fixed monthly wage is paid. If the individual WTA after one year is not balanced 
the employer has to pay also the overtime premium for the unbalanced part of the WTA if overtime premiums are generally negotiated. This is a controversial discussed point at the implementation of general minimum wage in Germany since January 2015. Namely, the introduction of the minimum wages can be delayed until one year. Especially during the Great Recession employers and employees have often concluded a no-premium agreement. Currently, the works councils try to discontinue this concession. Koch (2011) has pointed out that WTA are often introduced in conjunction with pacts of employment and employment guarantees.

\section{$3 \quad$ Related empirical literature}

Different studies exist on flexible working hours in Europe (Chung/Tijdens 2009, European Foundation for the Improvement of Living and Working Conditions 2012, 2012a, Platenga/Remery 2010). Chung and Tijdens (2009) present the working time arrangements in 21 EU member states, based on the Establishment Survey on Working Time 2004/2005. They group these into two bundles, namely in employee- and employer-centered arrangements. They find three country clusters: (1) Northern European countries including Poland and Czech Republic, (2) continental European and Anglo-Saxon countries and (3) southern European countries with Hungary and Slovenia. In countries of type (3) the average company does not use much working time arrangements. The country group (1) is characterized by an extensive use of employer- and employee-oriented working time arrangements. And finally, in (2) the employer-oriented working time component dominates. They report on the distribution and use of WTA in European countries on an aggregated level (European Foundation for the Improvement of Living and Working Conditions 2012a, p.15, Table 3). Around 70 percent of the establishments in the 27 EU countries have WTA, while only 22.7 percent of the companies have long-term WTA with a compensation period of more than 1 year. 
More detailed information on the use of WTA and their determinants is available from Germany (Bellmann/Gewiese 2004, Herzog-Stein/Zapf 2014, Lott 2013, Ludewig 2001, Wotschack/Hildebrandt 2007, Zapf 2012, Zickert 2007). Based on the IAB Establishment Panel, Bellmann et al. (2012) show that the proportion of WTA establishments has increased slightly between 2002 and 2008 and reached 45 percent in 2008. Long-term WTA with a compensation period of 2 years or more use only 2 percent of the establishments. The IAB Establishment Panel also provides information about the reason of longterm WTA. Descriptive statistics make clear that the proportion of the WTA adopted due to family leave has increased from 2002 to 2008. No clear trends could be observed for long-term WTA for further training, sabbaticals and working life reduction. The IAB Working Time Calculation shows strongly varying WTA balances within the period 1991-2010 with a dramatic slump in 2008 and 2009 and complete recovery in the following year (Zapf 2012, p.48). During the crisis working time credits of employees were eliminated. However, no significant different use of WTA is reported during the crisis compared with other years. Herzog-Stein / Zapf (2014) stress that WTA played an important role in overcoming the negative effects of the Great Recession in Germany. Their results are based on the WSI Works Council Survey. Zapf and Brehmer (2010) argue that the WTA were successful. Their major point is that companies with WTA have faster matched their working time with product demand during and after the Great Recession by the reduction of time credits within WTA arrangements than other firms.

The use of long-term WTA depends on firm size, share of female employees and the existence of works councils (Wotschack/Hildebrandt 2007). Large firms see advantages in a support of early retirement options. Small firms with a high female share of employees emphasize that the use long-term WTA helps at options for family leaves or temporary part-time. Zickert (2007) and Lott (2013) have discussed the relationship between long-term learning time accounts and further training. Based on the German Job Vacancy Survey of the IAB they found that in 2005 around a third of the establishments considered 
learning time accounts as useful. However, only 2.5 percent of the companies have used such an instrument. .

Empirical evidence of WTA effects is weak. Some experimental studies exist (Dutcher 2012). Often, determinants and effects of flexible working time are investigated but the specific impact of WTA is neglected (Drago et al. 2009, Possenriede 2014, Wolf/Beblo 2004). No detailed information exists on the specific WTA arrangement except in case studies, e.g. in Lindecke (2008). However, in the latter case no generalized statements on the effects of WTA are possible.

Empirical investigations on flexible working hours and WTA with large individual data sets solve this problem. This does not meet our main research interest because we want to analyze the effects on establishments. Nevertheless, the results can demonstrate in which way individuals are affected by WTA. This can reveal, in comparison with establishment analyses, whether firms and employees want to build time credits at the same time and want to remove them during the same period. If not, conflicts are possible. Generally positive associations between establishments' aims and the introduction of WTA can be jeopardized or destroyed by the individual use of WTA.

Cotti et al. (2014) and Possenriede/Platenga (2014) find that flexibility of working time is positively associated with job satisfaction. However, the causality is unclear. On the one hand, paid work and private life are better harmonized by flexibility of work and this increases the satisfaction. On the other hand, a positive demand shock may increase the number of working hours and decrease the individual satisfaction. Furthermore, this study cannot detect differences between men and women and also not between employees with and without children.

Further insights to effects of flexible working hours on employees are provided by Possenriede (2014) using Dutch household panel data from 2002 to 2010. He finds that moderate use of flexi-time does not affect employer-paid training and promotions except for female workers. Their chances of a promotion 
decrease if they make use of flexi-time. This latter result is in some contrast to the above outcome of insignificant differences between men and women. Frequent use of flexible arrangements by employees is sanctioned by the employer. In that regard, we do not know so much about the objectives of establishments in relation to flexi-time and WTA. Of more interest for the employer is the result that flexi-time is negatively associated with sickness absenteeism, especially with the duration of absence. The effects on the number of working hours are only moderate and in many cases ambiguous. Females seem to reduce their total working time if they have the chance to work flexi-time. If an increase is observed this is driven by more unpaid overtime hours. Higher work intensity and reciprocity, i.e. more hours for more flexibility as gift exchange in Akerlof's sense (Akerlof 1982), are possible explanations.

A specific kind of flexible working time is analyzed by Beckmann et al. (2015). Based on the German Socio-Economic Panel from 2003 to 2011 they investigate the impact of self-managed working time on employee effort. 13.9 to 15.0 percent of the employees could determine in this period their working time at their own discretion. Extra effort is measured by the difference between actual and contractual working hours. The effects on work morale, work intensity and shirking are the object of inquiry. The study finds higher effort of workers with self-managed working time in comparison to workers with fixed working hours. This means employers can benefit. However, when the investigation controls for observed and unobserved characteristics and endogeneity, this positive effect is only moderate. No effects are detected among women with children. The positive influence among men is mainly driven by strong work ethic and intrinsic motivation but not by extrinsic motivators. Increased effort cannot be explained by the theory of reciprocity. Employee's shirking as a reaction to self-managed working time is ruled out by this investigation.

Empirical investigations on WTA effects based on IAB Establishment Panel data are carried out by Bellmann/Gerner 2011, Gerner (2012) and Balleer et al. (2014). These studies are focused on the influence of WTA on economic establishment indicators during the Great Recession. WTA play only a 
moderate role on the employment (Bellmann/Gerner 2011). Using descriptive statistics and multivariate estimates, Gerner (2012) finds that during the crisis establishments that were strongly hit by reduced employment but this decline was smaller than their fall in sales. The bivariate analysis supports the hypothesis that WTA contribute to a less strong reduction of employment. Firms hoarded employees with a resulting lower productivity. A multivariate investigation cannot detect significant differences in the change of labor productivity between WTA and non-WTA firms. This could mean that WTA do not achieve the major objective, namely stabilization of employment.

Balleer et al. (2014) confirm these doubts. WTA were not the major driver of the stable employment level in Germany during the Great Recession. They find that the separation as well as hiring reactions to profit changes is similar in firms with and without WTA. The only significant effect of WTA is revealed by the reaction on STW. If revenue expectations increase the reduction of the number of short-time workers is larger in firms with WTA.

In sum, the empirical results so far cannot finally make clear whether WTA are generally beneficial for establishments. On the one hand, the adoption and the use of WTA have intensified in Europe, specially also in Germany. This speaks in favor of a successful instrument. On the other hand, during the Great Recession WTA were less successful in employment stabilization than expected.

\section{$4 \quad$ Data and descriptive statistics}

The data used in this study come from the German IAB Establishment Panel (Fischer et al. 2009). The panel started in 1993 with an annual survey of West German establishments and was extended to East Germany in 1996. The sample selection is representative for German states (Bundesländer), industries, and establishment size. 16,000 firms are questioned annually about a wide range of labor market topics. The interviews are conducted face-to-face by professional interviewers. This ensures a high data quality and a response rate of, on average 83 percent. 
Establishments covered employ one or more employees covered by social insurance. We use the surveys from 2008 to 2014. In practice, only variables from 2008 until 2013 are considered because some key information collected in year $\mathrm{t}$ pertains to the past year. In this period information of working time accounts (WTA) is available every year. Positive time credits of WTA are interpreted as overtime work. We know whether an establishment has WTA, measured as a dummy variable (WTA=1 if working time accounts exist; WTA $=0$ otherwise). A data problem arises related to WTA in the IAB Establishment Panel. The filtering procedure in the questionnaire differs in even and odd years. In even years firms without overtime work are excluded when it is asked whether WTA exist. In odd years they are included. This means the number of firms with WTA is lower in even years. Artificial cycles are induced. In order to clear up this incompatibility we have changed the WTA status in any year $(t)$ if in the year before (t-1) and after $(t+1)$ the statements differ, e.g. if we have observed WTA=0 in 2012 but WTA=1 in 2011 and 2013. Then we assume that WTA=1 in 2012 would be answered if the filter in 2012 would be the same as in 2011 and 2013. This adjustment is based on the guess that the abolishment of WTA does not follow in the next year, directly after the introduction of WTA. Costs of the introduction usually hinder such a mechanism.

In comparison with the previous year ( $t-1)$ we can determine after the data cleaning whether working time accounts were introduced in $\mathrm{t}($ intWTA $=1$ ) or in another year (intWTA=0). The development of these two indicators is presented in Figure 1 . We can see that the share of establishments with intWTA=1 is decreasing. .

Table 1 displays the statistically significant differences of firm characteristics between WTA and nonWTA firms based on the pooled data 2008-2013. We find that productivity is higher in firms with WTA. Relatively speaking, WTA help firms to produce more efficiently. Furthermore, we find that WTA in Germany are more likely to occur in larger firms than in smaller ones. This fact can also explain that, on average, WTA firms have greater total sales and investments than other establishments. Finally, it should 
be mentioned that WTA firms have more graduates and skilled workers. This table reveals that poor profits are less widespread in WTA than in non-WTA firms.

Figure 2 displays the development of labor productivity (sales per employee) in WTA and non-WTA firms. Over the complete period, the productivity of WTA firms is significantly higher than in other firms. The figure reveals stronger productivity fluctuations of non-WTA firms. This supports the notion that WTA contribute to stabilization. However, during the Great Recession working time accounts could not prevent a more pronounced contraction of productivity. An obvious decline is observed in 2009.

\section{$5 \quad$ Methods and econometric results}

\subsection{Empirical approach}

The starting point of multivariate estimates is the determination of the influence of working time accounts on labor productivity in order to compare with existing investigations. A first problem is the selection of control variables. For the labor productivity estimation the specification can be based on the production theory and a wide range of well-developed production functions. Nevertheless, the decision is unclear and we want to analyze further performance functions for that no clear theory exists. Therefore, we use the least angle regression selection -approach (LARS - Efron et al. 2004) to choose variables from available firm characteristics. Assume the productivity function (main equation) is

$$
\log \left(\text { PROD }_{i t}\right)=\beta_{0}+\beta_{1} W_{T A} A_{i t}+x_{i t}{ }^{\prime} \beta_{2}+u_{i t}=: \beta_{0}+\dot{x}_{i t}{ }^{\prime} \beta+u_{i t},
$$

where $i=1, \ldots, N$ is the index of firms, $t=1, \ldots, T$ is the index of time periods, $\beta^{\prime}=\left(\beta_{0}, \beta^{\prime}\right)=\left(\beta_{0}, \beta_{1}, \ldots, \beta_{k}\right)$ is the coefficient vector, $\mathrm{u}_{\mathrm{it}}$ is the error term. Then the following steps are necessary to obtain the LARS solution:

- $\quad$ Start with all coefficients equal to zero except $\beta_{0}$.

- $\quad$ Find the predictor $x_{j}$ most correlated with $\log (P R O D)$. 
- Increase the coefficient $\beta_{\mathrm{j}}$ in the direction of the sign of its correlation with $\log (\mathrm{PROD})$. Take residuals $u$ along the way. Stop when some other predictor $x_{k}$ has as strong a correlation with $u$ as $x_{j}$.

- Increase $\left(\beta_{\mathrm{j}}, \beta_{\mathrm{k}}\right)$ in their joint least squares direction, until some other predictor $\mathrm{x}_{\mathrm{m}}$ has as much correlation with the residual $u$.

- $\quad$ Stop this procedure until a new regressor reduces Mallows Cp criterion (Mallows 1973).

For the log productivity function $(\log (P R O D))$ the following determinants are selected:

(2) $X=$ (LABOR HOARDING, FIXED-TERM EMPLOYMENT, PART-TIME WORK, TEMPORARY WORK, OVERTIME WORK, log(GRADUATES), log(SKILLED WORKERS), EXTRA PAYMENTS, DEPARTED EMPLOYEES, LAY-OFFS, QUITS, MUTUAL DISMISSALS, RELOCATIONS, RETIREMENTS, EARLY RETIREMENTS, Iog(FIRM SIZE), PLANT CLOSURE, OUTSOURCING, STARBUST, REORGANIZATION, COMPETITIVE PRESSURE, NEW PRODUCTS, NEW PROCEDURES, TECHNICAL STATE, log(INVESTMENTS))

The order of the variables indicates their statistical importance. This means, the variable LABOR HOARDING is first selected by the least angle regression as the most important influence among the given set of establishment characteristics.

Pooled OLS estimates neglect possible unobserved establishment effects $\left(u_{i}\right)$. In this case we have $\mathrm{u}_{\mathrm{it}}=\mathrm{u}_{\mathrm{i}}+\varepsilon_{\mathrm{it}}$, where the latter term is the classical error term. Based on the Breusch-Pagan Lagrange multiplier approach, we can test whether the null hypothesis that no such effects exist has to be rejected. Hausman tests allow us to ascertain whether random or fixed effects estimates are superior. A further problem is the interdependency between productivity and WTA. On the one hand, WTA may decrease or increase the productivity, as described in Section 1. On the other hand, low productivity may induce the adoption of working time accounts in order to improve competitiveness. In this case, a WTA function is formulated (first-stage equation) 


$$
W_{T A} A_{i t}=\nu_{0}+\nu_{1} \log \left(P R O D_{i t}\right)+z_{i t}{ }^{\prime} \gamma_{2}+v_{i t}=: \nu_{0}+\underline{z}_{i t}{ }^{\prime} \gamma+v_{i t}
$$

If no convincing instruments are available, if traditional identifying information such as external instruments or repeated measurements is absent, Lewbel's approach (2012) for endogenous treatment effects (ETE) can be applied. This technique allows the identification of structural parameters in regression models with endogenous regressors. Identification is achieved by having regressors that are uncorrelated with the product of heteroskedastic errors. In the simplest version, instruments W can be generated by the product of the residuals from the reduced form of (3)

(3a) $\mathrm{WTA}_{\mathrm{it}}=\delta_{0}+\mathrm{x}_{\mathrm{it}}{ }^{\prime} \delta_{1}+\mathrm{z}_{\mathrm{it}}{ }^{\prime} \delta_{2}+\mathrm{r}_{\mathrm{it}}=: \delta_{0}+\ddot{x}_{\mathrm{it}}{ }^{\prime} \delta+\mathrm{r}_{\mathrm{it}}$

and the mean centered values $(\ddot{X}-$ mean $(\ddot{X}))$ of a regressor

(4) $\quad W=(\ddot{X}-\operatorname{mean}(\ddot{X}))^{\prime} r$.

Instead of $\ddot{X}$ a subset can be used and further instruments can be considered. The greater the degree of scale heteroskedasticity in the error process, the higher will be the correlation of the generated instruments with the included endogenous variables which are the regressands in the first-stage regression. In our case, this is the WTA equation. A problem with the pure ETE approach might be that W has also to be uncorrelated with the squared error term, that the instrument should not affect the variance of any common factor in the two error terms. If it would, then it would affect the covariance between the two error term, and this is not allowed. In other words, the usual problem of finding a good reason of why an instrument should be excluded from the outcome equation is now shifted onto the second moments. The incorporation of additional instruments could possibly reduce this problem. A restriction of the ETE procedure is that it is only suitable for cross-section and pooled data.

As an extension we estimate within two-stage least squares for panel-data models (W2SLS; Baltagi 2005, p.114) 


$$
\beta_{\mathrm{W} 2 S L S}=\left(\dot{\mathrm{X}}_{1}{ }^{\prime} \mathrm{P}_{\ddot{\mathrm{x}} 1} \dot{\mathrm{X}}_{1}\right)^{-1} \dot{\mathrm{X}}_{1}{ }^{\prime} \mathrm{P}_{\ddot{\mathrm{x}} 1} \dot{\mathrm{Y}}_{1} \quad \text { and } \quad \mathrm{V}\left(\beta_{\mathrm{W} 2 \mathrm{SLS}}\right)=\sigma^{2} \varepsilon_{11}\left(\dot{\mathrm{X}}_{1}{ }^{\prime} \mathrm{P}_{\ddot{\mathrm{x}} 1} \dot{\mathrm{X}}_{1}\right)^{-1} \text {, }
$$

where $\dot{X}=(W T A, X)$ are the determinants of the main structural equation (1) of our simultaneous two equation model. $\ddot{X}=(X, Z)$ include all exogenous variables of the complete model; $\sigma^{2} \varepsilon_{11}$ is the variance of the classical part of the error term in the main equation (1). Multiplied with the weight matrix $Q$ the following expressions are defined: $\dot{\mathrm{X}}_{1}=\mathrm{Q} \dot{\mathrm{X}}, \ddot{\mathrm{X}}_{1}=\mathrm{Q} \ddot{\mathrm{X}}$ and $\dot{\mathrm{y}}_{1}=\mathrm{Q} \ln P R O D$, where $\mathrm{Q}=I N T$ - P. The scalar $N$ is the number of firms and $\mathrm{T}$ the number of time periods. The matrix $\mathrm{P}$ is the Kronecker product between the identity matrix IN and the matrix of ones of dimension $\mathrm{T}$.

Well-founded instruments based on policy measures or institutional rules that are not correlated with the error term are not available. Therefore, identifying variables have to be constructed by observational information from the data set. The average industry WTA (a_indusWTA) or the average regional (a_regWTA) variable is a possibility. The disadvantage of these indicators is that if firms would never switch the region or industry, then these variables are time-invariant and would drop out of the model after applying a within or a first differences estimator.

Finally, we have decided to use the classified predicted probability of WTA (prWTA_c) as instrument and incorporated in the WTA function. The prWTA_c variable is determined in two steps. In the first step probit estimates of WTA are executed. Based on these estimates the establishment probabilities, that the firm has WTA, are calculated (prWTA). In the second step this variable is classified into 10 intervals (prWTA_c=1 if $0<$ prWTA $<=0.1$, prWTA_c $=2$ if $0.1<$ prWTA $<=0.2, \ldots$, prWTA_c $=10$ if $0.9<$ prWTA $<=1$ ). The intention of these constructions is obtaining two variables that are strongly correlated with WTA but uncorrelated with the error term of the main equation. Tests for endogeneity, weak instruments and overidentifying restrictions are used checking whether the applied identifying variables fulfill the necessary conditions. Also, this instrument can be criticized because identification comes only from the 
different functional form of prWTA_c compared with WTA. As we do not focus on causal effects but from a statistical view endogeneity problems shall be solved, the argument is not so relevant.

Potential productivity-related effects are not the only focus of WTA schemes. Additionally, we investigate whether existing overtime and short-time schedules provided additional motivations for introducing WTA. Following Addison et al. (2001), typical further performance indicators are: labor fluctuations, departures, hires, wages, innovation and profitability. In the public discussion it is often argued that overtime and short-time working are important reasons to adopt WTA. Additionally, we analyze whether productivity effects are mainly determined by sales or the number of employees. In detail, we investigate whether changes of firm size, measured by the number of employees, are more induced by changes in hiring or departures of workers. Then we test whether WTA also influence investments because innovations are expressed by investments and the latter also affect sales and productivity. A further channel may be a relationship between WTA and further training. A large number of hours can be accumulated in long-term accounts for further training with the consequence of higher productivity. The latter may have negative consequences for workers via higher work intensity. It is difficult to measure whether this hypothesis has any importance. One possibility is to check whether workers in WTA firms have a higher propensity to quit before retirement. Productivity is not the only indicator to evaluate whether WTA are beneficial for the establishments. Influence on the firms' costs is also relevant, especially on employee wages. Our last step is to test a relationship between profits and WTA. If there is a significantly positive correlation between these two indicators we have strong evidence that WTA are beneficial for firms. However, it is difficult to decide about the causality of such a correlation.

Finally, we investigate whether WTA effects on productivity, wages per employee and operating surplus differ between subgroups. On the one hand, we split into firms with high and low sales variability as well as in firms with a high and a low share of skilled workers. On the other hand, based on the maximal 
agreed compensation duration of time credits and time debits, the effects are compared. We distinguish between the following compensation periods: compensation period up to one year, longer than one year, no fixed compensation period. We also include trust-based working time, where the employer does not keep track of actual working time but the employee may keep a WTA. The hypotheses are the following: (i) the stronger the fluctuations of the product demand, the more a firm benefits from WTA; (ii) the lower the share of skilled workers, the more negative profit effects can be expected; (iii) the longer the compensation period, the more likely is it that actual working time matches with the actual demand for labor; (iv) trust-based working time is motivating combined with higher work intensity. We also investigate whether the relationship differs for workers with shift work and for WTA employees with a long compensation period. In the latter case, we distinguish between different reasons of long-term WTA.

\subsection{Econometric results for the entire sample}

As establishment characteristics we analyze the following performance variables, most of which are measured in logarithms $(\log ()$.$) : productivity, wages per employee, sales, firm size, determined by the$ number of employees, investments, number of hired and departed workers. Furthermore, dummies are account for whether overtime work, short-time work and further training exist. Finally, we are interested in the establishment's profits measured by a categorical variable. The IAB Establishment Panel reports whether the profit situation is very good, good, satisfactory, sufficient or poor. As an alternative we use the operating surplus (=sales-preliminary work-wages) as a proxy for profits.

OLS estimates - see Table 2, column OLS - provides no significantly positive WTA effects on productivity and weakly negative profits. Wages per employee and investments increase by WTA. The outcome displays also significant effects of working time accounts on other relevant firm indicators: the number of hired and departed workers are lower in WTA than in non-WTA establishments while overtime and short time work as well as further training are higher. This means that firms with WTA have a higher 
propensity than other firms to adopt overtime work and further training. An extension of overtime work is plausible when no overtime premiums have to be paid within the WTA bounds. Then, there are firm advantages. Further training might be a positive signal for the establishment to adopt WTA because higher productivity of the employees can be expected. However, there are resulting higher costs and WTA in the log(PRODUCTIVITY) estimation does not display the expected significant impact. A reason for this unexpected result might be the neglect of the interdependency between productivity and WTA - see Section 5.1 and the outcome of Table A1, column EXO.

As an alternative, Lewbel's approach for endogenous treatment effects (ETE) is applied - see Section 5.1. The estimates are presented in Table 2, column ETE. Here we find that WTA contribute to higher productivity but also to higher wage costs. Higher productivity is induced by higher sales but not by fewer employees. It seems that workers in WTA firms have a lower propensity to quit. This is in accord with the OLS estimation and indicates that workers see flexible working time by WTA by and large as advantageous.

Additionally, it should be stressed that the positive WTA effects on investments are confirmed. So far, WTA reveal predominately positive effects for the firms. The net influence on wages is ambiguous. On the one hand, labor costs increase. On the other hand, indirect positive productivity effects are possible explained by the efficiency wage theory. Insofar, the negative profit effect in WTA regimes is surprising and unfavorable for the establishments.

As an extension of the analysis we undertake instrumental variables panel estimates as the ETE approach can only be applied for pooled data without unobserved establishment effects. The hypothesis of no time-invariant establishment effects is rejected - see Table A1, column BP. Furthermore, we analyze whether WTA effects differ in the short- and in the long-run. This means now we isolate the effects following the incorporation of a WTA regime (intWTA). The estimates are presented on the right hand 
side of Table 3, where only firms with WTA=1 are taken into account. This means establishments that had never WTA during the considered period are excluded.

The productivity, sales, investment and overtime effects of WTA are significantly positive. As productivity is measured by sales per employee, we have also conducted separate estimates for sales and firm size. We find that the productivity effect is driven by sales but not by firm size, determined by the number of employees. The latter is not affected by WTA. However, we can argue that external mobility is not affected by WTA. The number of quits does not fall but also not more new workers are hired. External mobility, extensive margin adjustments is not substituted by more variability of working hours via WTA, by more intensive margin adjustments.

In contrast to the ETE estimates we do not find significant wage and further training effects of WTA. The profit effect is as in Table 2 negative. A comparison of estimates between the fixed and random effects approach - the latter are not in the tables - displays for all performance indicator estimates the same sign of the WTA coefficients if both are significant.

For the productivity function the complete estimates with and without industry and region dummies are shown in Table A3. Besides the positive WTA effect we find that labor hoarding significantly reduces productivity, while reallocations and reorganizations enhance productivity. In some sense the productivity function can be interpreted as an extended Cobb Douglas function. The LARS procedure has selected the typical input factors, (skilled) labor and investment in logs, as relevant determinants.

The interpretation of the profit effect in Table 3 is not so obvious. As in the OLS and the ETE estimates no positive profit effects of WTA are revealed. The negative sign of the coefficient means that profits are lower in WTA companies than in other firms. Increasing wages per employee do not seem a decisive factor. The WTA effect is insignificant. Under-investment might be a reason. In the short-run we find some evidence to this hypothesis - see $\beta$ (intWTA) in Table 3 , line $\log ($ INVESTMENTS). The adoption of a 
WTA system induces a decline of investments. In the long-run, the sign of the permanent WTA effect on investment is positive. Higher investment costs are a consequence. Further causes via indirect channels might be responsible for lower profits. To find possible influences, the profit specification in Table 3 is extended by interactions of the regressors with WTA. We find - not in the tables - that interactions of LABOR HOARDING, EXTRA PAYMENTS, REORGANIZATION, NEW PRODUCTS, NEW PROCEDURES and $\log ($ INVESTMENTS) with WTA have weak significant and positive effects on profits. All these influences speak in favor of WTA for the firms. Furthermore, we should stress that labor hoarding reduces profits because labor costs increase. However, in WTA firms this negative impact is overcompensated. The hoarded labor can be better distributed in time by WTA.

So far, the puzzle of negative WTA effects on profits is not completely solved. First, the crude measurement of profits may be the reason. As an alternative we have used the operating surplus (OS= sales-preliminary work-wages). Also in this case the sign is negative but the effect is insignificant - see Table 3, column ß(WTA), line log(operating surplus). This means OS does not differ statistically between WTA and NON-WTA establishments. Second, costs of WTA installation and operating costs may be responsible for negative WTA effects on profits. No information exists about this issue. Third, negotiating power of employees can be another explanation. If skilled workers are especially interested in flexible working time, they have the power to enforce WTA because they can threaten to reduce their working intensity. Establishments accept the introduction of WTA because otherwise the fall in productivity would be higher than the saving of WTA costs. If the share of graduates and skilled workers is low, if the staff has no threat potential, a company can forego WTA. The descriptive statistics in Table 1 show that the share of graduates and skilled workers is significantly higher in WTA than in other firms. Nevertheless, it cannot be excluded that the employer adopts WTA although the share of graduates and skilled workers is low. Then we expect lower profits. This topic is analyzed under 5.3. 
We should add some further insights on the initial effects of WTA (intWTA). In contrast to permanent WTA the effects on productivity are negative immediately following the introduction of WTA. We guess that the distribution of time credits is not coordinated between the employer and the employees in the beginning. Then productivity losses may result. The same pattern is observed for investments and further training - a reduction immediately after the WTA adoption but positive effects in the long-run. Reasons are initial uncertainty about the success of WTA, about the further economic development of the firm combined with waiting to invest (Pindyck 1991) or substitution of WTA costs by lower costs of additional input factors. A further remarkable outcome is the prompt increase of overtime work. This result is stable under a short- and long-term consideration and over all applied methods in this study. Repeating the argument, lower or no overtime premiums under a WTA regime make overtime more attractive for the companies. Finally, we should emphasize that profit losses and reduced operating surplus are also induced by the introduction of WTA.

\subsection{Results for subgroups - robustness or heterogeneity?}

First, we test whether the results are robust or heterogeneous for specific industries and firms. Second, we analyze whether the influences of WTA on firms' performance indicators vary under specific types of WTA. Following section 5.2, the sample in Table 3 is split into firms with high and lower shares of graduates and skilled workers. No significant loss of profits can be observed under a WTA regime when the share of qualified workers in the establishment is high - see Table 4(1a). This result does not change when operating surplus instead of the categorical profit variable is used - see Table 4(1b). Nevertheless, so far the sign of all WTA effects on profits and operating surplus is negative. Therefore, we follow another line of argument. Firms introduce WTA to achieve a better adaptation of working hours to fluctuations of goods demand in order to increase profits. In this case, firms with stronger sales fluctuations are more interested in WTA. We test whether WTA effects on operating surplus are more likely positive the more sales vary. First, we ask whether this hypothesis can be confirmed at an industry 
level. Second, we investigate the firm level. Sales fluctuations are measured by the variation coefficient (v) of $\log ($ sales). In panel (2) of Table 4, industry results are presented. Based on industries with high and low $\mathrm{v}$, we find that in the former WTA induce positive OS effects. In industries with small fluctuations we observe the opposite result. This outcome is strengthened on firms' level - see panel (3) of Table 4. The 25 percent firms with the highest variation coefficient $(v)$ of sales have positively significant WTA effects on operating surplus. Other firms do not benefit on average from working time accounts. For the profit variable the results are not so clear but with the same tendency - see panel (4) of Table 4. Profits do not distinguish between WTA and non-WTA firms with strong sales fluctuations. If fluctuations are smaller, WTA firms reveal significantly negative effects on profits.

In our next step, we investigate whether the WTA effects are robust or heterogeneous under different types of WTA. Information on subgroups to WTA is only available in 2008, 2010 and 2012 in the IAB Establishment Panel. In Table 5a, line 1-3 the percentage of firms with WTA, but differently agreed compensation periods is presented. Three groups are distinguished: less or equal 1 year $(C P<=1 Y)$, more than 1 year $(\mathrm{CP}>1 \mathrm{Y})$ or no fixed compensation period (noFCP). It can be seen that the share of firms with $\mathrm{CP}<=1 \mathrm{Y}$ is the largest one but decreasing in recent years. The opposite tendency is observed for firms with no fixed compensation period, however at a lower level. WTA with a longer compensation period are less widespread and no clear development is identifiable.

Rows 4 to 7 in Table 5a show the distribution on four reasons of long-term WTA. In all cases the percentage is low. Advanced further training (AFTRAIN) and parental leave (PARLEAVE) are even less widespread than the other two options but all four with a rising trend.

In line 8 and 9 of Table 5a we distinguish between two instruments of control of the working time, between trust-based (TBWT) and shifted working time (SWT) of individual workers or teams. The percentage of firms with the latter regulation is higher than the former. More than 50 percent use SWT. 
Both options can also be found in NON-WTA firms. It is obvious that there TBWT and SWT are less widespread - see Table 5b.

The left-hand side instrumental variables estimates of Table 3 are extended by an interaction term between WTA and a subgroup indicator, measured by a dummy variable (see Table 5a). In Table 6 we present nine different random (RE) and fixed effects (FE) estimates, where we restrict our analysis on productivity and wages per employee (WpE) effects and where we only show the WTA and the interaction coefficient. The control variables are the same as in Table 3. Based on Hausman tests analogously to Table A2 but not presented in the tables - the FE estimates should be preferred although the RE estimates indicate a higher degree of significance. The signs of the coefficients are the same in RE and FE estimates. It should be noted that in most estimations the FE coefficients are absolutely larger than that of the RE coefficients in the productivity function. The opposite is observed in the wage function.

We limit the following to the FE results. First, only two of the interaction variables are found to have significant effects on the wage per employee. All WTA coefficients stay positive as in Table 3, left-hand side, line 1 and 2 . In the $\log$ (PRODUCTIVITY) estimations most WTA influences are weakly significant. The interaction variable reduces the pure WTA influences in all cases. However, in all nine specifications of the $\log$ (PRODUCTIVITY) function the difference between the WTA coefficient and the coefficient of the interaction variable is larger than the WTA coefficient in Table $3(\beta($ WTA)), e.g. $\beta($ WTA - Table 6)$\beta($ WTA*CPle1Y - Table 6$)-\beta($ WTA - Table 3$)=2.809-0.605-0.514=1.69>0$. Short compensation periods have stronger effects than longer ones. In other words, the positive WTA effects on productivity decrease with the length of compensation periods. On a first view, this does not seem plausible because longer compensation periods mean more flexibility. Then it is not necessary to balance positive credits because the compensation period has ended though possibly employees and employer would prefer longer working time with the consequence of higher productivity. However, the longer the compensation 
period, the lower are the incentives to work harder. In some sense the time preference is effective. The earlier longer working hours are compensated by leisure, the more the employees try to work well with a high intensity.

One could expect that the WTA effect is lower if no compensation period is agreed. This is observed in comparison with a one-year compensation period but not in comparison with a longer compensation period. Insofar, the coefficient of the interaction WTA*noFCP is surprising. However, no fixed compensation period include also cases of no restriction. And then in practice the horizon can be very long.

The reasons, why long-term WTA are used (sabbatical, advanced further training, reduction in the number of working years, parental leave), do not influence WTA effects on productivity. We cannot find significant differences. The motivation of a longer working time out is without importance for the shortrun productivity. Whether long-run effects follow, cannot be investigated with the available data set.

An interesting but in some sense unexpected result is the negative coefficient of WTA*TBWT. The hypothesis is that self-managed working hours are mainly permitted for qualified workers in responsible positions and from this group high productivity is anticipated. However, this is not empirically confirmed. For example, in 2008 among the graduates in a firm 22 percent have on average trust-based working time, while among the group of workers with simple activities 26 percent are independently managing their working time. Within the latter group, self-exploitation combined with long working time and low productivity, on the one hand, and the lack of monitoring, on the other hand, can explain the empirical outcome of a negative coefficient.

\section{Conclusions}

Flexible working time has been intensively analyzed in the past. Economists, psychologists and sociologists have investigated the determinants and the effects on both employees and companies. One 
aspect that is becoming more important in practice in recent years, namely working time accounts (WTA), has not been in the center of empirical investigations. To date there exist only a few studies on this that use individual or firms data for this purpose.

Our investigations allow new insights into the operation of WTA and help to detect for which firms WTA are beneficial. The results demonstrate that German WTA contracts might be a role model for some other countries. "Working time accounts ... have the potential to further boost flexibility for both employers and employees. However, they are not widely available in all countries ..." (European Foundation for the Improvement of Living and Working Conditions 2012).

The intention of our paper is to demonstrate that WTA influence the business processes through different channels. This hitherto has been an under-researched area. Our empirical investigations show that the major question asks whether firms benefit from WTA and whether WTA help to increase the firm performance cannot simply be answered by yes or no. We find, when unobserved firm effects, WTA endogeneity, and firm characteristics are considered, that WTA firms in comparison to other firms have

- $\quad$ a significantly higher productivity;

- $\quad$ higher investments;

- $\quad$ on average the same wages per employee;

- $\quad$ no higher employment;

- $\quad$ worked more overtime hours;

- $\quad$ on average, the same operating surplus but lower profits.

These results are not valid for all subgroups of firms and are based on existing WTA but not on the initial effects when WTA were introduced. The latter distinguish in some items from the former. In the short- 
run, we cannot detect positive productivity effects. Investments decline and firm size tends to a smaller workforce. Shorter compensation periods of time credits and debits under WTA arrangements should be preferred under the productivity perspective. The seemingly contradiction that WTA increase productivity and do not enhance wages per employee but induce lower profits can be resolved. Other costs like WTA or investment costs may emerge.

Our major conclusions are: WTA have positive effects on firms' productivity, especially if not a too long compensation period of time credits is agreed. No net changes of wages are observed by WTA. Less extensive than intensive margin adjustments is a consequence of WTA. The profit effect is ambiguous. A negative impact is less likely when the firm has a high share of graduates and skilled workers. The operating surplus increases under WTA arrangements if product demand and in consequence labor demand varies over time in an unforeseeable way.

All in all our results support the hypothesis that the installation of WTA is a compromise between the interests of the employers and the employees. The former gain by higher productivity and by less workers' fluctuations. This strengthens the competiveness and helps to weaken problems of skills shortage. Furthermore firms can save overtime premiums. Wages do not fall, however. Higher productivity is the reason. In the sense of gift exchange workers increase their labor intensity as compensation to their right to arrange their working time more flexible. WTA and other costs usually hinder higher profits in the short run except if sales are highly volatile.

WTA are not a panacea. If the macroeconomic demand for goods is characterized by an economic slump as during the Great Recession in 2009 the balancing force of WTA is not sufficient to hinder layoffs. This is only the case if fluctuations are short and foreseeable. For this purpose, the economic policy should support the adoption of WTA in the interest of establishments and workers. Adaption costs can be subsidized. Such an instrument is less expensive than short time work. Furthermore, employees prefer 
WTA more than company level pacts because the latter are associated with certain problems. Employers pledges are not always fulfilled (Hübler 2005, Bellmann 2014). Investments are a by-product of WTA and are not necessarily associated with specific concessions of the employees within company level pacts.

Future research might usefully be twofold. First, the analysis needs to be supplemented by further studies with individual data. Then we can better evaluate in what extend establishment results are driven by individual preferences on working time accounts. Second, it would be instructive to carry out analogous empirical investigations in other countries. 


\section{References}

Addison, J. T., C. Schnabel and J. Wagner (2001), Works councils in Germany: their effects on establishment performance, Oxford Economic Papers 53, 659-694.

Akerlof, G. A. (1982), Labor contracts as partial gift exchange, Quarterly Journal of Economics 97:4, 543569.

Baltagi, B. H. (2005), Econometric analysis of panel data, 3rd ed., John Wiley \& Sons.

Balleer, A., B. Gehrke and C. Merkl (2014), Some surprising facts about working time accounts and the business cycle, Kiel Working Paper No. 1955.

Beckmann, M., T. Cornelissen and M. Kräkel (2015), Self-managed working time and employee effort: theory and evidence, SOEPpapers No. 768.

Bellmann, L. (2014), Do in-plant alliances foster employment? IZA World of Labor.

Bellmann, L., P. Ellguth and H.-D. Gerner (2012), Betriebliche Arbeitszeiten - Auswertungen des IABBetriebspanels. In: Becker-Stoll, F., Klös, H.-P., Rainer, H. \& G. Thüsing (Hrsg.), Expertisen zum Achten Familienbericht „Zeit für Familie“, München, 397-418.

Bellmann, L. and H.-D. Gerner (2011), Reversed roles? Wage and employment effects of the current crisis. In: H. Immervoll, A. Peichl \& K. Tatsiramos (Hrsg.), Who loses in the downturn? Economic crisis, employment and income distribution, Bingley: Emerald, 181-206.

Bellmann, L. and T. Gewiese (2004), Die Dynamik der Nutzung von Arbeitszeitkonten - theoretische Ansätze und Längsschnittanalysen mit dem IAB-Betriebspanel. In: L. Bellmann und C. Schnabel (Hrsg.), Betriebliche Arbeitszeitpolitik im Wandel, BeitrAB 288, Nürnberg, 139-184.

Bellmann, L. and O. Ludewig (2000), Verbreitung von Arbeitszeitkonten in Deutschland, arbeit und beruf, 137-139.

Berg, P., E. Appelbaum, T. Bailey and A. L. Kalleberg (2004), Contesting time: International comparisons of employee control of working time, Industrial and Labor Relations Review 57:3, 331-349.

Brewster, C., L. Mayne and O. Tregaski (1997), Flexible working in Europe, Journal of World Business $32: 2,133-151$.

Carstensen, V. (2013), The German labor market miracle revisited: risk elimination in working time accounts, Eurasian Journal of Social Sciences 1:1, 19-38.

Chung, H. and K. Tijdens (2009), Working time flexibility components of companies in Europe, University of Amsterdam, Working Paper 09-84.

Cotti, C.D., M.R. Haley and L.A. Miller (2014), Workplace flexibilities, job satisfaction and union membership in US workforce, British Journal of Industrial Relations 52:3, 403-425. 
Crompton, R. (2002), Employment, flexible working and the family, The British Journal of Sociology 53:4, 537-558.

Dex, S. and F. Scheibl (2001), Flexible and family-friendly working arrangements in UK - Based SMEs: Business Cases, British Journal for Industrial Relations 39:3, 411-431.

Drago, R., M. Wooden and D. Black (2009), Who wants and gets flexibility? Changing work hours preferences and life events, Industrial and Labor Relations Review 62:3, 394-414.

Dutcher, E.G. (2012), The effects of telecommuting on productivity: An experimental examination - the role of dull and creative tasks, Journal of Economic Behavior and Organization 84:1, 353-363.

Efron, B., T. Hastie, I. Johnstone and R. Tibshirani (2004), Least angle regression. Annals of Statistics 32, 407-451.

European Foundation for the Improvement of Living and Working Conditions (2012), Working time in the EU, Dublin.

European Foundation for the Improvement of Living and Working Conditions (2012a), Organisation of working time: Implications for productivity and working conditions - overview report, Dublin.

Fischer, G., F. Janik, D. Müller and A. Schmucker (2009), The IAB Establishment Panel - Things Users Should Know, Journal of Applied Social Science Studies 129, 133-148.

Gerlach, K. (2004), Wirtschaftspolitisches Forum - Arbeitszeitflexibilisierung: Welche Modelle entlasten den Arbeitsmarkt? Zeitschrift für Wirtschaftspolitik 3/2004, 1-6.

Gerner, H.-D. (2012), Die Produktivitätsentwicklung und die Rolle von Arbeitszeitkonten während der Großen Rezession 2008/2009: Ergebnisse auf der Grundlage des IAB Betriebspanels, Zeitschrift für Personalforschung 26, 30-47.

Golden, L. (2012), The effects of working time on productivity and firm performance: a synthesis research paper, Conditions of Work and Employment Series No. 33, International Labour Office, Geneva.

Groß, H. (2009), Vergleichende Analyse der Arbeits- und Betriebszeitenanalyse im Zeitraum 1987 bis 2007. Dortmund: Sozialforschungsstelle.

Groß, H., E. Munz, and H. Seifert (2000), Verbreitung und Struktur von Arbeitszeitkonten, Arbeit 9:3, 217229.

Herzog-Stein A. and I. Zapf (2014), Navigating the Great Recession: The impact of working-time accounts in Germany, Industrial and Labor Relations Review 67:3, 891-925.

Houseman, S. N. (2001), Why employers use flexible staffing arrangements: Evidence from an establishment survey, Industrial and Labor Relations Review 55:1, 149-170.

Hübler, O. (2005), Sind betriebliche Bündnisse für Arbeit erfolgreich? Jahrbücher für Nationalökonomie und Statistik 225/6, 630-652. 
Kelliher, C. and D. Anderson (2010), Doing more with less? Flexible working practices and the intensification of work, Human Relations 63:1, 83-106.

Koch, S. (2011), Arbeitszeitkonten stabilisieren die Beschäftigung. Arbeitszeit und Arbeitsvolumen - Teil II. IAB Kurzbericht Nr. 4.

Kouzis, G. and L. Kretsos (2003), Annualised hours in Europe, EurWORK: European Observatory of Working Life. European Industrial Relations Observatory.

Lewbel, A. (2012), Using heteroscedasticity to identify and estimate mismeasured and endogenous regressor models, Journal of Business and Economic Statistics 30:1, 67-80.

Lindecke, C. (2008), Flexible Arbeitszeiten im Betrieb - Betriebs- und Dienstvereinbarungen. Fallstudien, Bund-Verlag, Frankfurt a.M.

Lott, M. (2013), Arbeitszeitverkürzung für Weiterbildung im Spiegel betrieblicher Einschätzung, WSI Mitteilungen 66:4, 255-263.

Ludewig, O. (2001), Betriebliche Bestimmungsgründe von Arbeitszeitkonten, Mitteilungen aus der Arbeitsmarkt- und Berufsforschung 34, 302-313.

Mallows, C. L. (1973), Some comments on CP, Technometrics 15, 661-676.

Orpen, C. (1981), Effect of flexible working hours on employee satisfaction and performance: A field experiment, Journal of Applied Psychology 66:1, 113-115.

Pindyck, R. S. (1991), Irreversibility, uncertainty, and investment, Journal of Economic Literature 29, 1110-1148.

Platenga, J. and C. Remery (2010), Flexible working time arrangements and gender equality. A comparative review in 30 European countries, Rome.

Possenriede, D. (2014), The economics of temporal and locational flexibility of work, Diss. Utrecht.

Possenriede, D. and J. Platenga (2014), Temporal and locational flexibility of work, working-time fit and job satisfaction, IZA DP No. 8436.

Schein, V. E., E. H. Maurer and J. F. Novak (1977), Impact of flexible working hours on productivity, Journal of Applied Psychology 62:4, 463-465

Seifert, H. (2004), Flexibility through working-time accounts: reconciling economic efficiency and individual time requirements, WSI Discussion Paper No. 130.

Wolf, E. and M. Beblo (2004), Does work time flexibility work? ZEW Discussion Paper No. 04-47.

Wotschack, P. and E. Hildebrandt (2007), Long-term working-time accounts and life-course policies. Preliminary results of a representative company survey. WZB discussion paper No. SP I 2007-109. 
Zapf, I. (2012), Flexibilität am Arbeitsmarkt durch Überstunden und Arbeitszeitkonten. Messkonzepte, Datenquellen und Ergebnisse im Kontext der IAB-Arbeitszeitrechnung, IAB-Forschungsbericht 3/2012, Nürnberg.

Zapf, I. and W. Brehmer (2010), Arbeitszeitkonten haben sich bewährt, IAB-Kurzbericht 22/2010.

Zickert, K. (2007), Förderung der beruflichen Qualifizierung durch Weiterbildungs- und Arbeitszeitmanagement. Ergebnisse einer Betriebsbefragung, IAB-Forschungsbericht, Nr. 11/2007. 


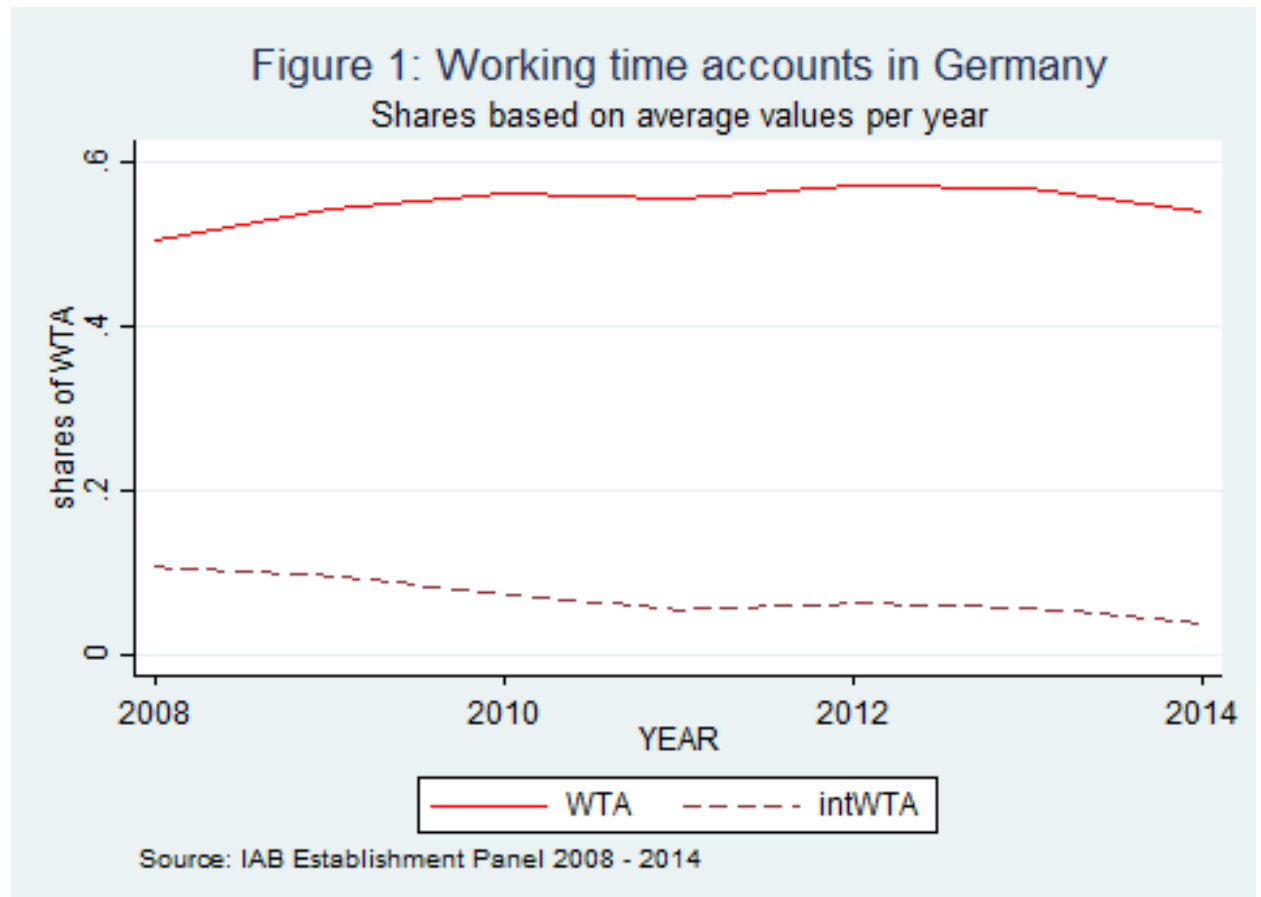


Figure 2: Firm productivity split by WTA and non-WTA firms Germany 2008-2013

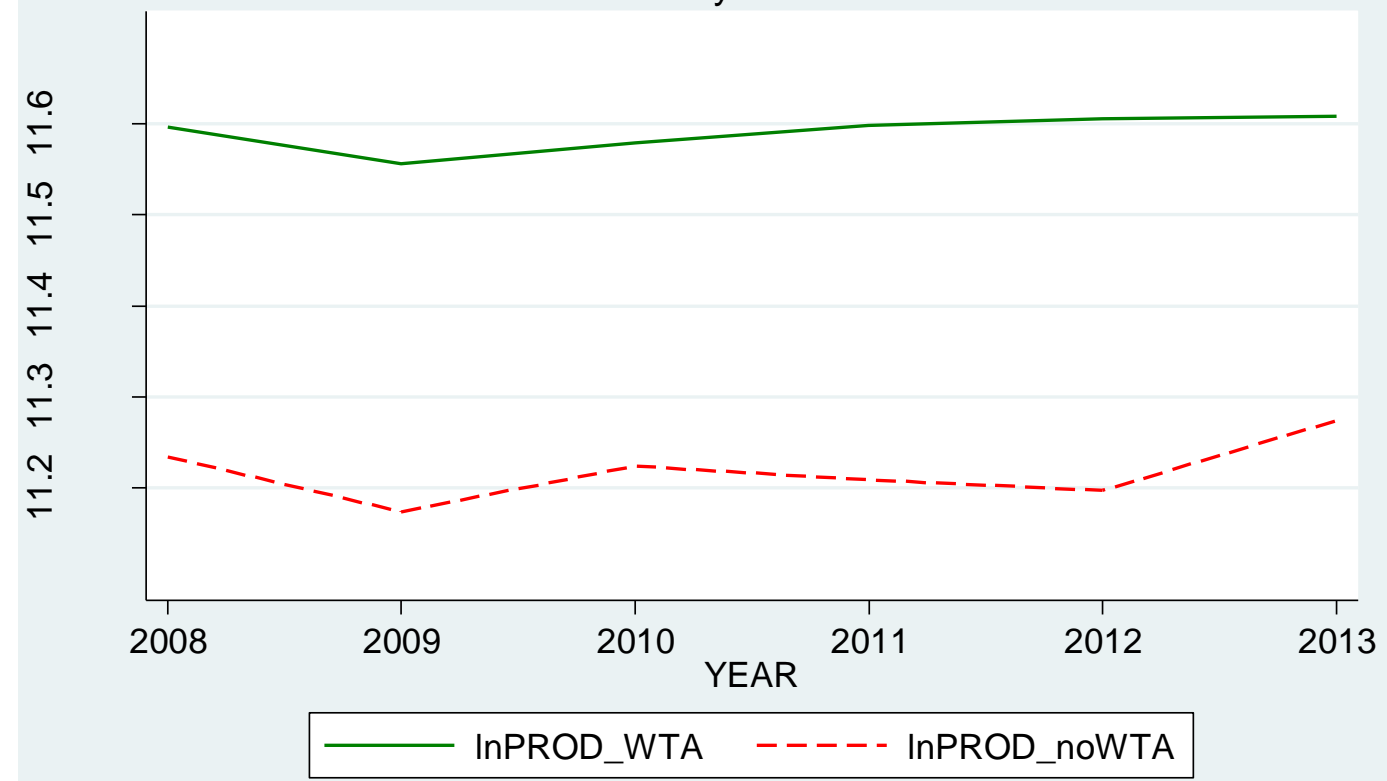

Source: IAB Establishment Panel 
Table 1: Descriptive statistics of establishment characteristics, split by WTA and non-WTA firms and pooled over 2008-2013 and $t$ tests of difference between means of the two types of firms

\begin{tabular}{|c|c|c|c|c|c|}
\hline & WTA $=1$ & & WTA $=0$ & & $\mathrm{t}$ test \\
\hline & mean & sd & mean & sd & $t$ value \\
\hline log(PRODUCTIVITY) & 11.600 & $(0.93)$ & 11.215 & $(0.96)$ & $76.42 * * *$ \\
\hline log(WAGES per EMPLOYEE) & 7.599 & $(0.50)$ & 7.189 & $(0.66)$ & $150.54 * * *$ \\
\hline $\log (\mathrm{SALES})$ & 15.371 & $(2.10)$ & 13.654 & $(1.78)$ & $167.26 * * *$ \\
\hline $\log (F I R M ~ S I Z E)$ & 3.908 & $(1.66)$ & 2.500 & $(1.40)$ & $183.04 * * *$ \\
\hline log(INVESTMENTS) & 12.181 & (2.39) & 10.645 & $(2.05)$ & $148.10^{* * *}$ \\
\hline $\log ($ HIRED WORKERS) & 1.443 & $(1.30)$ & 0.989 & (1.19) & $51.32 * * *$ \\
\hline $\log ($ FIRED WORKERS) & 1.387 & $(1.32)$ & 0.906 & $(1.18)$ & $53.39 * * *$ \\
\hline $\log (G R A D U A T E S)$ & 1.534 & $(1.83)$ & 0.520 & $(1.13)$ & $159.35 * * *$ \\
\hline $\log ($ SKILLED WORKERS) & 3.333 & $(1.75)$ & 1.823 & $(1.47)$ & $184.34^{* * *}$ \\
\hline $\log ($ OPERATING SURPLUS) & 14.477 & $(1.99)$ & 12.856 & $(1.71)$ & $160.05^{* * *}$ \\
\hline OVERTIME WORK & 0.815 & $(0.39)$ & 0.449 & $(0.50)$ & $175.71 * * *$ \\
\hline SHORT-TIME WORK & 0.158 & $(0.36)$ & 0.083 & $(0.28)$ & $29.31 * * *$ \\
\hline FURTHER TRAINING & 0.817 & $(0.39)$ & 0.564 & $(0.50)$ & $52.84 * * *$ \\
\hline PROFITS & 3.302 & $(1.02)$ & 3.183 & $(1.00)$ & $23.72 * * *$ \\
\hline LABOR HOARDING & 0.454 & $(0.50)$ & 0.530 & $(0.50)$ & $-34.04^{* * *}$ \\
\hline PART-TIME WORK & 0.851 & $(0.36)$ & 0.769 & $(0.42)$ & $46.83 * * *$ \\
\hline TEMPORARY WORK & 0.207 & $(0.41)$ & 0.055 & $(0.23)$ & $99.61 * * *$ \\
\hline EXTRA PAYMENTS & 0.206 & $(0.40)$ & 0.108 & $(0.31)$ & $59.24 * * *$ \\
\hline REORGANIZATION & 0.026 & $(0.16)$ & 0.008 & $(0.09)$ & $29.87 * * *$ \\
\hline COMPETITIVE PRESSURE & 2.996 & $(1.04)$ & 2.910 & $(1.01)$ & $18.56^{* * *}$ \\
\hline NEW PRODUCTS & 0.511 & $(0.50)$ & 0.351 & $(0.48)$ & $72.18 * * *$ \\
\hline NEW PROCEDURES & 0.225 & $(0.42)$ & 0.105 & $(0.31)$ & $72.07 * * *$ \\
\hline TECHNICAL STATE & 2.172 & $(0.72)$ & 2.257 & $(0.77)$ & $-25.30 * * *$ \\
\hline
\end{tabular}


Table 2: Ordinary least squares (OLS) and estimates of regressions with endogenous treatment effects (ETE) for different establishment performance functions with a working time accounts (WTA) dummy as a regressor.

$\begin{array}{lllll} & \text { OLS } & & \text { ETE } & \\ & \beta(\text { WTA }) & \text { std.err } & \beta(\text { WTA }) & \text { std.err } \\ \log (\text { PRODUCTIVITY) } & 0.004 & 0.010 & 0.107^{* * *} & 0.024 \\ \log (\text { WAGES per EMPLOYEE) } & 0.073^{* * *} & 0.004 & 0.327^{* * *} & 0.010 \\ \log (\text { SALES) } & 0.011 & 0.010 & 0.143^{* * *} & 0.024 \\ \log (\text { FIRM SIZE) } & -0.017^{* * *} & 0.005 & 0.093^{* * *} & 0.012 \\ \log (\text { INVESTMENTS) } & 0.171^{* * *} & 0.015 & 1.092^{* * *} & 0.040 \\ \log (\text { HIRED WORKERS) } & -0.114^{* * *} & 0.008 & -0.663^{* * *} & 0.024 \\ \log (\text { DEPARTED WORKERS) } & -0.154^{* * *} & 0.007 & -0.602^{* * *} & 0.019 \\ \log (\text { OPERATING SURPLUS) } & 0.012 & 0.009 & 0.108^{* * *} & 0.022 \\ \text { OVERTIME WORK } & 0.181^{* * *} & 0.004 & 1.107^{* * *} & 0.012 \\ \text { SHORT-TIME WORK } & 0.062^{* * *} & 0.006 & 0.133^{* * *} & 0.015 \\ \text { FURTHER TRAINING } & 0.063^{* * *} & 0.003 & 0.170^{* * *} & 0.008 \\ \text { PROFITS } & -0.019^{*} & 0.010 & -0.277^{* * *} & 0.027\end{array}$

Notes: Control variables are LABOR HOARDING, FIXED-TERM EMPLOYMENT, PART-TIME WORK, TEMPORARY WORK, log(GRADUATES), log(SKILLED WORKERS), EXTRA PAYMENTS, MUTUAL DISMISSALS, RELOCATION, RETIREMENTS, DOWN PERIOD, OUTSOURCING, STARBUSTS, REORGANIZATION, COMPETITIVE PRESSURE, NEW PRODUCTS, NEW PROCEDURES, TECHNICAL STATE, Y2008, Y2009, Y2010, Y2011, Y2012. Some variables are only incorporated as regressors if they are not the endogenous variables: $\log ($ FIRM SIZE), $\log ($ INVESTMENTS), QUITS. PROFITS are measured by an ordinal scale: 1 - poor, 2 - sufficient, 3 - satisfactory, 4 - good, 5 - very good. Further ordinal scaled variables are competitive pressure $(1$ - no pressure, 2 - minor pressure, 3 - medium pressure, 4 substantial pressure) and technical state (1 - state of the art, ... , 5 - obsolete).The WTA variable is instrumented by $\mathrm{W}$ - see equation (4) - for the ETE estimates. A further identifying variable is prWTA_c; robust standard errors; ${ }^{*}$ $\mathrm{p}<0.1,{ }^{* *} \mathrm{p}<0.05, * * * \mathrm{p}<0.01$. 
Table 3: Fixed effects instrumental variables estimates for different establishment performance functions with WTA and intWTA, respectively, as regressor.

$\begin{array}{lllll} & \beta(\text { WTA }) & \text { std.err. } & \beta \text { (intWTA) } & \text { std.err. } \\ \log (\text { PRODUCTIVITY) } & 0.457^{* *} & 0.193 & -0.825^{* * *} & 0.159 \\ \log (\text { WAGES per EMPLOYEE) } & 0.117 & 0.119 & -0.044 & 0.037 \\ \log (\text { SALES) } & 1.089^{* * *} & 0.393 & -1.104^{* * *} & 0.172 \\ \log \text { (FIRM SIZE) } & 0.117 & 0.092 & -0.157^{* * *} & 0.029 \\ \log (\text { INVESTMENTS) } & 15.952^{* * *} & 2.745 & -1.431^{* * *} & 0.259 \\ \log (\text { HIRED WORKERS) } & 1.206 & 1.098 & -0.009 & 0.202 \\ \log (\text { DEPARTED WORKERS) } & 0.300 & 0.413 & -0.338^{* *} & 0.147 \\ \log (\text { OPERATING SURPLUS) } & 0.117 & 0.261 & -0.468^{* *} & 0.227 \\ \text { OVERTIME WORK } & 9.769 * * * & 0.538 & 0.986^{* * *} & 0.083 \\ \text { SHORT-TIME WORK } & 0.051 & 0.127 & 0.111 & 1.132 \\ \text { FURTHER TRAINING } & 0.139 & 0.138 & -0.239^{* * *} & 0.049 \\ \text { PROFITS } & -3.246^{* * *} & 0.960 & -1.103^{*} & 0.298\end{array}$

Notes: Control variables are LABOR HOARDING, FIXED-TERM EMPLOYMENT, PART-TIME WORK, TEMPORARY WORK, $\log$ (GRADUATES), log(SKILLED WORKERS), EXTRA PAYMENTS, MUTUAL DISMISSALS, RELOCATION, RETIREMENTS, DOWN PERIOD, OUTSOURCING, STARBUSTS, REORGANIZATION, COMPETITIVE PRESSURE, NEW PRODUCTS, NEW PROCEDURES, TECHNICAL STATE, Y2008, Y2009, Y2010, Y2011, Y2012. Some variables are only incorporated as regressors if they are not the endogenous variables: $\log ($ FIRM SIZE), $\log ($ INVESTMENTS). The WTA variable is instrumented. The identifying variable is prWTA_c ; robust standard errors; ${ }^{*} p<0.1,{ }^{* *} p<0.05, * * *$ $\mathrm{p}<0.01$. 
Table 4: Working time accounts (WTA) effects on profits and operating surplus (OS)

B_WTA std.err restriction

(1) Firms with high and low shares of graduates and skilled workers

(a) WTA effect on PROFITS

(i) $-2.292 \quad 3.123 \quad$ share of graduates $>=0.7$ or share of skilled workers $>=0.7$

(ii) $\quad-2.518^{*} \quad 1.495 \quad$ share of graduates $<0.3$ or share of skilled workers $<0.3$

(b) WTA effect on operating surplus (OS)

(i) $\quad-0.337 \quad 0.629 \quad$ share of graduates $>=0.7$ or share of skilled workers $>=0.7$

(ii) $\quad-0.592^{* * *} \quad 0.279 \quad$ share of graduates $<0.3$ or share of skilled workers $<0.3$

(2) Industries with large and small sales fluctuations measured by the variation coefficient (v) - WTA effects on OS

(i) $\quad 2.530 \quad 1.877 \quad$ INDUSTRY =mining and quarrying $(v=0.151)$

(ii) $\quad 2.979 \quad$ INDUSTRY $=$ manufacture of motor vehicles $(v=0.188)$

(iii) $\quad 0.350 \quad 0.267 \quad$ INDUSTRY $=$ recreational and cultural activities $(v=0.183)$

(iv) $-1.591^{*} \quad 0.911 \quad$ INDUSTRY =agriculture, hunting, forestry, fishing $(v=0.102)$

(v) $\quad-4.970 \quad 3.869 \quad$ INDUSTRY $=$ architecture, engineering offices $(v=0.108)$

(vi) $\quad-0.421 \quad 0.449 \quad$ INDUSTRY =education $(v=0.105)$

(3) Firms with large and small sales fluctuations measured by v - WTA effects on OS

(i) $1.340 * * * \quad 0.503 \quad$ firms with the $25 \%$ largest sales fluctuations

(ii) $-0.145 \quad 0.161 \quad$ firms with the $75 \%$ smallest sales fluctuations

(4) Firms with large and small sales fluctuations measured by v - WTA effects on PROFITS

(i) $-14.234 \quad 10.016 \quad$ firms with the $25 \%$ largest sales fluctuations

(ii) $-1.389 * \quad 0.737 \quad$ firms with the $75 \%$ smallest sales fluctuations

Notes: The specifications are the same as in Table 3; $* p<0.1, * * p<0.05$ and $* * * p<0.01$. 
Table 5a: Descriptive statistics of WTA subgroups, split by years $(2008,2010$ and 2012)

2008

2010

2012

$\begin{array}{lllllll} & \text { mean } & \text { sd } & \text { mean } & \text { sd } & \text { mean } & \text { sd } \\ \text { CP<=1Y } & 0.594 & (0.49) & 0.573 & (0.49) & 0.551 & (0.50) \\ \text { CP>1Y } & 0.130 & (0.34) & 0.142 & (0.35) & 0.134 & (0.34) \\ \text { noFCP } & 0.275 & (0.45) & 0.283 & (0.45) & 0.314 & (0.46) \\ \text { SABBAT } & 0.040 & (0.20) & 0.042 & (0.20) & 0.062 & (0.24) \\ \text { AFTRAIN } & 0.018 & (0.13) & 0.022 & (0.15) & 0.045 & (0.21) \\ \text { RWL } & 0.044 & (0.21) & 0.046 & (0.21) & 0.057 & (0.23) \\ \text { PARLEAVE } & 0.026 & (0.16) & 0.035 & (0.18) & 0.054 & (0.23) \\ \text { TBWT } & 0.299 & (0.46) & 0.289 & (0.45) & 0.304 & (0.46) \\ \text { SWT } & 0.521 & (0.50) & 0.518 & (0.50) & 0.593 & (0.49)\end{array}$

Notes: WTA - working time accounts; $s d$ - standard deviation; $\mathrm{CP}<=1 \mathrm{Y}$ - compensation period lower equal 1 year; $\mathrm{CP}>1 \mathrm{Y}$ - compensation period greater than 1 year; noFCP - no fixed compensation period; SABBAT - sabbatical; AFTRAIN - advanced further training; RWT - reduction in the length of working life in years; PARPLEAVE - parental leave; TBWT - trust-based working time; SWT - shifted working time of individual workers or teams.

Table 5b: Descriptive statistics of NON-WTA subgroups, split by years (2008, 2010 and 2012)

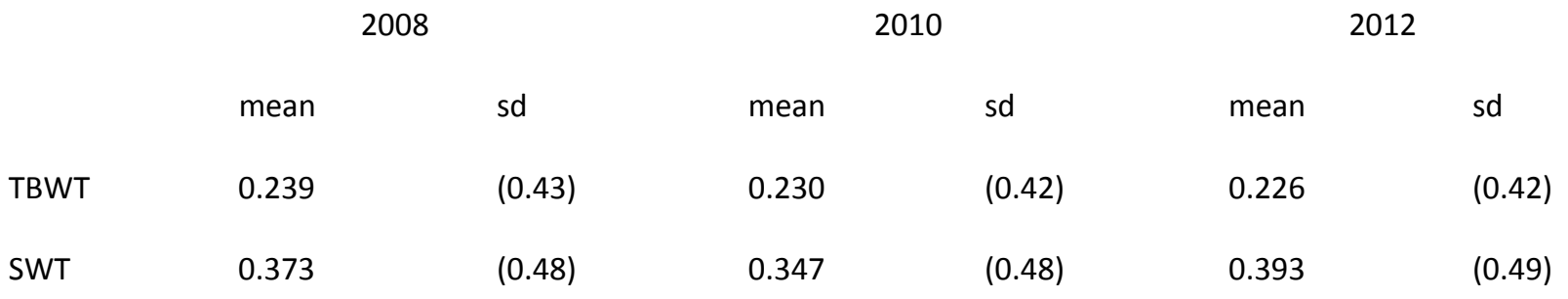


Table 6: Instrumental variables panel estimates for subgroups - the influence of specific working time accounts on productivity and wages per employee.

\begin{tabular}{|c|c|c|c|c|c|}
\hline & $\log (P R O D)$ & & $\log (W p E)$ & & \\
\hline & RE & $\mathrm{FE}$ & RE & $\mathrm{FE}$ & \\
\hline WTA & $1.689 * * *(0.332)$ & $2.809 *(2.793)$ & $1.472^{* * *}(0.392)$ & 1.064 & $(1.363)$ \\
\hline $\mathrm{WTA}^{*} \mathrm{CP}<=1 \mathrm{Y}$ & $-0.580 * * *(0.124)$ & $-0.605(0.630)$ & $-0.367 * * *(0.098)$ & -0.262 & $(0.327)$ \\
\hline WTA & $1.141^{* * *}(0.203)$ & $2.327 \quad(2.050)$ & $0.646^{* * *}(0.146)$ & 0.246 & $(0.169)$ \\
\hline$W T A^{*} C P>1 Y$ & $-0.347^{* * *}(0.071)$ & $-0.455(0.396)$ & $-0.139 * * *(0.028)$ & $-0.060 *$ & * $(0.032)$ \\
\hline WTA & $1.244^{* * *}(0.223)$ & 2.164 (1.807) & $0.703^{* * *}(0.170)$ & 0.263 & $(0.197)$ \\
\hline WTA*noFCP & $-0.305^{* * *}(0.065)$ & $-0.350(0.275)$ & $-0.088^{* * *}(0.025)$ & -0.024 & $(0.028)$ \\
\hline WTA & $1.120^{* * *}(0.220)$ & $2.029 *(1.635)$ & $0.812^{* * *}(0.190)$ & 0.359 & $(0.244)$ \\
\hline WTA*TBWT & $-0.206 * * *(0.061)$ & $-0.331(0.274)$ & $-0.146^{* * *}(0.033)$ & $-0.072 *$ & * $(0.041)$ \\
\hline WTA & $1.272^{* * *}(0.224)$ & $3.548 \quad(4.243)$ & $1.267^{* * *}(0.205)$ & 1.146 & $(1.270)$ \\
\hline WTA*SWT & $-0.551^{* * *}(0.095)$ & $-0.828(1.054)$ & $-0.333^{* * *}(0.054)$ & -0.285 & $(0.317)$ \\
\hline WTA & $1.120^{* * *}(0.177)$ & $3.553 *(1.897)$ & $0.934 * * *(6.72)$ & 0.193 & $(0.344)$ \\
\hline WTA*SABBAT & $-0.107 \quad(0.079)$ & $-0.043(0.150)$ & -0.041 & -0.009 & $(0.023)$ \\
\hline WTA & $1.122^{* * *}(0.177)$ & $3.513 *(1.832)$ & $0.923 * * *(0.137)$ & 0.181 & (0.329) \\
\hline WTA*AFTRAIN & $-0.128 \quad(0.088)$ & $-0.127(0.155)$ & -0.042 & -0.009 & $(0.022)$ \\
\hline WTA & $1.117^{* * *}(0.177)$ & $3.673 *(1.972)$ & $0.933 * * *(0.139)$ & 0.190 & (0.342) \\
\hline WTA*RWL & $-0.069 \quad(0.079)$ & $-0.237(0.188)$ & $-0.061 * *(0.028)$ & -0.012 & $(0.031)$ \\
\hline WTA & $1.124^{* * *}(0.178)$ & $3.550 *(1.880)$ & $0.931^{* * *}(0.139)$ & 0.187 & (0.335) \\
\hline WTA*PARLEAVE & $(0.081)$ & $-0.027(0.137)$ & $\begin{array}{ll}-0.025 & (0.025)\end{array}$ & -0.009 & (0.019) \\
\hline
\end{tabular}

Notes: Basic control variables are the same as in Tables 2 and 3. Additionally, interaction variables between WTA and the following variables are incorporated: $\mathrm{CP}<=1 \mathrm{Y}$ - compensation period within a year; $\mathrm{CP}>1 \mathrm{Y}-$ compensation period more than 1 year; noFCP - no fixed compensation period; TBWT - trust-based working time; SWT - shifted working time of individual workers or teams; SABBAT - sabbaticals; AFTRAIN - advanced further training; RWL reduction in the length of working life in years; PARLEAVE - parental leave. The WTA variable is instrumented as in Table 3. Robust standard errors are in parentheses; ${ }^{*} p<0.1,{ }^{* *} p<0.05, * * * p<0.01$. 
Table A1: Specification tests for different establishment performance indicator functions with WTA as a regressor

$\begin{array}{llllll} & \text { BP } & \text { HAUS } & \text { EXO } & \text { OIR } & \text { WI } \\ \log (\text { PRODUCTIVITY) } & 6691^{* * *} & 1068^{* * *} & 71.47^{* * *} & 0.04 & 171.34 \\ \log (\text { WAGES per EMPLOYEE) } & 6481^{* * *} & 697^{* * *} & 372.84^{* * *} & 0.29 & 248.12 \\ \log (\text { SALES) } & 6658^{* * *} & 2249^{* * *} & 81.27^{* * *} & 0.26 & 174.10 \\ \log (\text { FIRM SIZE) } & 9955^{* * *} & 8438^{* * *} & 8.35^{* * *} & 117.33^{* * *} & 281.77 \\ \log (\text { INVESTMENTS) } & 5397^{* * *} & 280^{* * *} & 423.09^{* * *} & 0.10 & 294.00 \\ \log (\text { HIRED WORKERS) } & 3129^{* * *} & 344^{* * *} & 354.05^{* * *} & 17.40^{* * *} & 220.86 \\ \log (\text { DEPARTED WORKERS) } & 3913^{* * *} & 162^{* * *} & 296.17^{* * *} & 22.15^{* * *} & 284.47 \\ \log (\text { OPERATING SURPLUS) } & 15,83^{* * *} & 2008^{* * *} & 247.48^{* * *} & 33.80^{* * *} & 923.37 \\ \text { OVERTIME WORK } & 2810^{* * *} & 130^{* * *} & 3862.50^{* * *} & 268.64^{* * *} & 499.74 \\ \text { SHORT-TIME WORK } & 270^{* * *} & 113^{* * *} & 97.46^{* * *} & 87.95^{* * *} & 101.12 \\ \text { FURTHER TRAINING } & 1066^{* * *} & 161^{* * *} & 44.70^{* * *} & 66.11^{* * *} & 278.09 \\ \text { PROFITS } & 1775^{* * *} & 148^{* * *} & 13.89^{* * *} & 0.68 & 180.72\end{array}$

Notes: We test H_O for no time invariant firm effects (Breusch-Pagan test - BP), no correlation between firm effects and regressors (random vs. fixed (Hausman test - HAUS)), exogeneity (Durbin-Wu-Hausman test - EXO), no overidentifying restrictions (OIR) und weak instruments (Stock-Yogo test - WI). Test statistics are presented in the table, where BP, HAUS, EXO and OIR are $\chi^{2}$ distributed. WI are minimum eigenvalue statistics. All test statistics in column WI indicate that the eigenvalue is larger than the critical value at $p<0.05$, that $H_{-} 0$ (weak instruments) has to be rejected; * $p<0.1, * * p<0.05, * * * p<0.01$. 
Table A2: Specification tests for different establishment performance indicator functions with introduction of working time accounts (intWTA) as a regressor.

$\begin{array}{llllll} & \text { BP } & \text { HAUS } & \text { EXO } & \text { OIR } & \text { WI } \\ \log (\text { PRODUCTIVITY) } & 6712^{* * *} & 1050^{* * *} & 37.92^{* * *} & 0.02 & 39.27 \\ \log (\text { WAGES per EMPLOYEE) } & 6502^{* * *} & 2715^{* * *} & 108.77^{* * *} & 15.96^{* * *} & 56.24 \\ \log (\text { SALES) } & 6682^{* * *} & 2259^{* * *} & 34.77^{* * *} & 0.002 & 39.54 \\ \log (\text { FIRM SIZE) } & 9985^{* * *} & 8814^{* * *} & 10.74^{* * *} & 5.93^{* *} & 58.97 \\ \log (\text { INVESTMENTS) } & 5492^{* * *} & 277^{* * *} & 51.29^{* * *} & 23.24^{* * *} & 60.04 \\ \log (\text { HIRED WORKERS) } & 3209^{* * *} & 343^{* * *} & 46.64^{* * *} & 1.40 & 38.68 \\ \log \text { (DEPARTED EMPLOYEES) } & 4027^{* * *} & 209^{* * *} & 71.36^{* * *} & 0.25 & 59.76 \\ \log (\text { OPERATING SURPLUS) } & 15,630^{* * *} & 2022^{* * *} & 75.25^{* * *} & 122.80^{* * *} & 52.81 \\ \text { OVERTIME WORK } & 2845^{* * *} & 101^{* * *} & 62.89^{* * *} & 24.32^{* * *} & 55.23 \\ \text { SHORT-TIME WORK } & 272^{* * *} & 108^{* * *} & 61.41^{* * *} & 34.67^{* * *} & 17.83 \\ \text { FURTHER TRAINING } & 1099^{* * *} & 164^{* * *} & 5.56^{* *} & 9.64^{* * *} & 58.01 \\ \text { PROFITS } & 1780^{* * *} & 149 * * * & 0.003 & 3.39 * & 45.99\end{array}$

Notes: We test H_O for no time invariant firm effects (Breusch-Pagan test - BP), no correlation between firm effects and regressors (random vs. fixed (Hausman test - HAUS)), exogeneity (Durbin-Wu-Hausman test - EXO), no overidentifying restrictions (OIR) und weak instruments (Stock-Yogo test - WI). Test statistics are presented in the table, where BP, HAUS, EXO and OIR are $\chi^{2}$ distributed. WI are minimum eigenvalue statistics. All test statistics in column WI indicate that $H_{-} 0$ has to be rejected at $p<0.05$. The sample is restricted on establishments with WTA=1; $* p<0.1, * * p<0.05, * * * p<0.01$. 
Table A3: Log productivity - $\log (P R O D)$ - fixed-effects, instrumental variables estimates

\begin{tabular}{|c|c|c|}
\hline Variable | & \multicolumn{2}{|c|}{$\log (P R O D)$} \\
\hline WORKING TIME ACCOUNTS | & $0.4572^{* *}$ & $0.4568 * *$ \\
\hline $\log (G R A D U A T E S) \mid$ & 0.0036 & 0.0020 \\
\hline log(SKILLED WORKERS) | & $0.0445 * * *$ & $0.0443 * * *$ \\
\hline $\log (F I R M ~ S I Z E) \mid$ & $-0.0793 * * *$ & $-0.0784 * * *$ \\
\hline $\log ($ INVESTMENTS) | & $0.0148 * * *$ & $0.0143 * * *$ \\
\hline LABOR HORDING | & $-0.0770 * * *$ & $-0.0753^{* * *}$ \\
\hline FIXED-TERM EMPLOYMENT | & 0.0058 & 0.0048 \\
\hline PART-TIME WORK I & 0.0081 & 0.0111 \\
\hline TEMPORARY WORK I & -0.0017 & -0.0026 \\
\hline OVERTIME WORK | & -0.0113 & -0.0117 \\
\hline EXTRA PAYMENT I & -0.0005 & 0.0007 \\
\hline DEPARTED EMPLOYEES | & $-0.0012^{* * *}$ & $-0.0012^{* * *}$ \\
\hline LAY-OFFS | & 0.0003 & $0.0004^{* *}$ \\
\hline QUITS | & $0.0016^{* * *}$ & $0.0015^{* * *}$ \\
\hline MUTUAL DISMISSALS | & $-0.0006 * *$ & $-0.0005^{* *}$ \\
\hline RELOCATION | & $0.0011^{* * *}$ & $0.0011^{* * *}$ \\
\hline RETIREMENTS | & 0.0003 & 0.0003 \\
\hline EARLY RETIREMENTS | & $0.0013^{* * *}$ & $0.0013 * * *$ \\
\hline PLANT CLOSURE | & $-0.0764 * * *$ & $-0.0758 * * *$ \\
\hline OUTSOURCING | & $-0.0469 * *$ & $-0.0483^{* *}$ \\
\hline STARBUST | & $-0.1770 * * *$ & $-0.1833^{* * *}$ \\
\hline REORGANIZATION | & $0.0774 * * *$ & $0.0719 * * *$ \\
\hline COMPETITIVE PRESSURE | & -0.0015 & -0.0014 \\
\hline
\end{tabular}




\begin{tabular}{|c|c|c|}
\hline NEW PRODUCTS | & 0.0044 & 0.0028 \\
\hline NEW PROCEDURES | & $-0.0188 * * *$ & $-0.0176 * * *$ \\
\hline TECHNICAL STATUS | & $-0.0246 * * *$ & $-0.0246 * * *$ \\
\hline Y2008 | & $0.0346 * * *$ & $0.0585^{* * *}$ \\
\hline Y2009 | & $0.0250 * * *$ & $0.0247 * * *$ \\
\hline Y2010 | & $-0.0489 * * *$ & $-0.0490 * * *$ \\
\hline Y2011 | & -0.0053 & -0.0049 \\
\hline Y2012 | & $0.0137 * *$ & $0.0141 * *$ \\
\hline INDUSTRIES | & no & yes \\
\hline REGIONS | & no & yes \\
\hline $\mathrm{N}$ I & 47824 & 47824 \\
\hline Number of groups | & 2787 & 2787 \\
\hline
\end{tabular}

Notes: WTA is instrumented by prWTA_c. On the right hand side besides year dummies also 14 industry dummies and 16 regional dummies (Bundesländer) are incorporated; ${ }^{*} p<0.1 ; * *<<0.05 ; * * *<<0.01$. 